\title{
Field Survey of Cucumber mosaic virus Subgroups I and II in Crop Plants in Costa Rica
}

\author{
M. J. Hord, A. García, H. Villalobos, C. Rivera, and G. Macaya, Centro de Investigación en Biología Celular y \\ Molecular, Universidad de Costa Rica, San Pedro, Costa Rica; and M. J. Roossinck, The Samuel Roberts Noble \\ Foundation, Ardmore, OK 73402
}

\begin{abstract}
Hord, M. J., García, A., Villalobos, H., Rivera, C., Macaya, G., and Roossinck, M. J. 2001. Field survey of Cucumber mosaic virus subgroups I and II in crop plants in Costa Rica. Plant Dis. 85:952-954.

Leaf samples were collected from cucurbit and solanaceous crop plants and Musa spp. in 28 locations in five provinces of Costa Rica during the period from January to October 1996. Sampling sites were selected in dry, humid, and moist tropical regions ranging in altitude from 50 to 2,100 m above sea level. RNA-enriched total nucleic acid solutions were spotted onto nylon membranes and hybridized to RNA probes specific for Cucumber mosaic virus (CMV) subgroups I or II. The presence of CMV was confirmed in 13 crops in 23 of the 28 sampling sites. CMV subgroup I was found to predominate in Costa Rica. CMV subgroup II was detected in the Atlantic region only, and in only 1 out of $113 \mathrm{CMV}$-positive samples.
\end{abstract}

Cucumber mosaic virus (CMV) is the type species of the genus Cucumovirus in the family Bromoviridae (11). The three genomic segments of CMV are singlestranded, plus-sense RNA molecules of approximately $3,400,3,000$, and 2,200 nt that are encapsidated in isometric particles (7). The numerous strains of CMV have been classified into two major subgroups by serological relationships and nucleotide sequence similarity (7), and subgroup I has been further divided into two groups by phylogenetic analyses (14).

CMV is readily transmitted in a styletborne, nonpersistent manner by more than 75 species of aphids (7). It has a host range of more than 1,000 species of plants (4). Among the susceptible species are several crops of economic importance in Costa Rica, including cucurbit and solanaceous crops and Musa spp. CMV is one of four viruses causing significant losses in export melons in the provinces of Guanacaste and Puntarenas, Costa Rica (9). In these provinces, melons are grown continuously during a 3- to 6-month period. Climatic conditions during the melon production season are favorable for aphid populations, which tend to increase dramatically throughout the season. Weekly plantings provide a

Corresponding author: M. J. Roossinck

E-mail: mroossinck@noble.org

This work was funded by the United States Agency for International Development, grant no. HRN-5600-G-00-2013-00.

Accepted for publication 18 April 2001.

Publication no. D-2001-0614-02R

(C) 2001 The American Phytopathological Society continuous source of susceptible tissue (9). Consequently, the incidence of CMV infection can approach $100 \%$ by the end of the growing season (5). Numerous weed species and other cucurbit crops serve as inoculum reservoirs from one growing season to the next (15). Although both CMV subgroups have been detected in melon in western Costa Rica, subgroup I occurs more frequently (5). In addition, both CMV subgroups have been identified in banana in Costa Rica (8). However, the occurrence of CMV in other crops and geographic areas in Costa Rica has not been studied. The present survey was undertaken to determine the presence of CMV in cucurbit and solanaceous crops and Musa spp. in diverse ecological zones in Costa Rica.

\section{MATERIALS AND METHODS}

Sample collection and RNA extraction. Leaf samples (approximately $100 \mathrm{mg}$ each) were collected from cucurbit and solanaceous crop plants and Musa spp. in 28 locations in five provinces of Costa Rica during the period from January to October 1996. Sampling sites were selected in dry, humid, and moist tropical regions ranging in altitude from 50 to 2,100 m (Table 1). In all, 284 samples were collected. In general, no more than 10 samples per crop were collected at random (i.e., without regard to symptoms) at each site. The banana samples were not collected at random, but were selected based on symptoms of possible virus infection. Samples were maintained at $-70^{\circ} \mathrm{C}$ until processed. RNA-enriched total nucleic acid solutions were prepared by the method described previously (12). Final ethanol precipitate pellets were dried and resuspended in $40 \mu \mathrm{l}$ of $0.1 \mathrm{mM}$ EDTA, and stored at $-20^{\circ} \mathrm{C}$.

Viral cDNA clones and radiolabeled RNA probe synthesis. Six recombinant plasmids were used for $\alpha-{ }^{32} \mathrm{P}$-labeled RNA probe synthesis by standard techniques. Plasmids F1C, F2C, and F3C were derived from full-length cDNA clones of Fny CMV (10,13), and contained conserved sequences of CMV subgroup I RNAs 1, 2, and 3, respectively (5). Plasmids pLS1, pLS2, and pLS3 (gift of P. Palukaitis) contained full-length cDNA of CMV subgroup II RNAs 1, 2, and 3, respectively (17). Plasmids were linearized by digestion with the appropriate restriction enzymes prior to transcription of plus-sense transcripts to be used as positive controls, and minus-sense ${ }^{32} \mathrm{P}$-labeled RNA probes, with either SP6, $\mathrm{T} 7$, or T3 bacteriophage polymerases, as described previously (1).

Hybridization. Nucleic acid preparations $(15 \mu \mathrm{l})$ were spotted onto nylon membranes (Hybond $\mathrm{N}+$ ) and fixed by exposure to UV light for $30 \mathrm{~s}$ prior to hybridization. Controls included on each membrane consisted of RNA extracted from purified CMV isolates Fny (subgroup I) and Beer (subgroup II), an isolate from zucchini squash from upstate New York, and positive-sense RNA transcripts exactly complementary to the probes used. RNA probes transcribed from plasmids F1C, F2C, and F3C were used for detection of CMV subgroup I. RNA probes transcribed from pLS1, pLS2, and pLS3 were used for detection of CMV subgroup II. A mixture of the three probes for each subgroup was used in the hybridization. Membranes were prehybridized for $20 \mathrm{~min}$ at $70^{\circ} \mathrm{C}$ in $5 \mathrm{ml}$ of hybridization buffer (1\% bovine serum albumin, $1 \mathrm{mM}$ EDTA, $0.5 \mathrm{M}$ $\mathrm{NaPO}_{4}, \mathrm{pH} 7.2,7 \%$ sodium dodecyl sulfate [SDS]). Radiolabeled probes $\left(6 \times 10^{6}\right.$ $\mathrm{cpm})$ were added to the prehybridization buffer and hybridization proceeded at $70^{\circ} \mathrm{C}$ overnight. Membranes were washed four times with $0.1 \times \mathrm{SSC}(0.15 \mathrm{M} \mathrm{NaCl}$ plus $0.015 \mathrm{M}$ sodium citrate) and $2 \%$ SDS at 65 to $70^{\circ} \mathrm{C}$ for $20 \mathrm{~min}$ each and exposed to X-ray film at $-70^{\circ} \mathrm{C}$ with intensifying screens for 2 to $24 \mathrm{~h}$. Membranes were stripped of the probe by washing in boiling water.

\section{RESULTS AND DISCUSSION}

The presence of CMV was detected in 13 crops in 23 of the 28 sampling sites in 
Costa Rica (Table 1). CMV subgroup I was found to predominate. A total of 113 samples $(40 \%)$ were positive for CMV subgroup I (Table 2). CMV subgroup II was not detected in cucurbit or solanaceous crops. The only sample positive for subgroup II was a banana sample from the Limón province which was also infected area comes from a variety of sources and includes both old stock corms and micropropagated, tissue-culture-grown plantlets. Although some viruses have been reported to be carried through tissue culture in banana $(2,3)$, it is not known if CMV is or if the micropropagated banana is a source of CMV in the field.

These findings demonstrate the widespread occurrence of CMV subgroup I in a wide range of climatic zones in Costa Rica, including dry, humid, and moist tropical regions. The incidence of CMV at each site was not determined, but the detection of the virus with only a small number of samples (usually no more than 10 samples with CMV subgroup I. Banana from this

collected randomly at each site) indicates that the incidence was very high in the vegetable crops. Although samples were taken over a period of 10 months, a majority of the samples were collected during March, near the end of the dry season. With the exception of the banana samples, no bias toward symptomatic plants was used in sampling; however, virus symptoms become more prevalent during the later part of the dry season (unpublished observation).

The prevalence of CMV subgroup I in Costa Rica is consistent with a previous report that this subgroup is predominant in tropical and subtropical zones, whereas subgroup II is more frequently found in temperate regions (16). However, numerous reports have described CMV from many parts of the world without differentiating subgroups $(4,6)$. In general, subgroup I strains induce a more severe disease in crop plants, and the high incidence found in this study in several Costa Rican crops underscores the importance of appropriate

Table 1. Sampling sites and crops included in survey for Cucumber mosaic virus (CMV)

\begin{tabular}{|c|c|c|c|}
\hline Crop $^{a}$ & County & Province & Altitude (m) \\
\hline Cucumis ficifolia & Naranjo & Alajuela & 1,700 \\
\hline Cucumber, tobacco & Naranjo & Alajuela & 1,000 \\
\hline Tobacco & Naranjo & Alajuela & 1,000 \\
\hline Tobacco & Palmares & Alajuela & 1,000 \\
\hline Squash, chili pepper, cucumber & San Carlos & Alajuela & 300 \\
\hline Pumpkin, chili pepper, watermelon, tomato & San Carlos & Alajuela & 300 \\
\hline Cucumber, Cucurbita argyrosperma, tomato & Upala & Alajuela & 400 \\
\hline Petunia & Cartago & Cartago & 1,400 \\
\hline Squash, cucumber & El Guarco & Cartago & 1,500 \\
\hline Zapallo squash & Oreamuno & Cartago & 1,700 \\
\hline Zucchini & Paraiso & Cartago & 1,000 \\
\hline Bell pepper & Paraiso & Cartago & 1,000 \\
\hline Zucchini & Paraiso & Cartago & 1,300 \\
\hline Eggplant & Santiago & Cartago & 1,100 \\
\hline Squash, Cyclanthera pedata & Santiago & Cartago & 1,200 \\
\hline Watermelon, chili pepper & Bagaces & Guanacaste & 100 \\
\hline Watermelon & Bagaces & Guanacaste & 150 \\
\hline Squash, Cucurbita argyrosperma, watermelon & Cañas & Guanacaste & 100 \\
\hline Jalapeño, canteloupe & Carrillo & Guanacaste & 50 \\
\hline Canteloupe & Liberia & Guanacaste & 100 \\
\hline Butternut squash, watermelon & Nandayure & Guanacaste & 50 \\
\hline Canteloupe, Cucurbita argyrosperma, watermelon & Nicoya & Guanacaste & 200 \\
\hline Musa spp. & Pocosí & Limón & 100 \\
\hline Watermelon & Palmares & San José & 600 \\
\hline Zucchini & Pérez Zeledón & San José & 2,100 \\
\hline Squash & Pérez Zeledón & San José & 1,000 \\
\hline Squash & Puriscal & San José & 800 \\
\hline Cucumber & Santa Ana & San José & 900 \\
\hline
\end{tabular}

${ }^{a}$ Bold letters indicate the presence of CMV.

Table 2. Detection of Cucumber mosaic virus (CMV) subgroup I in five provinces of Costa Rica by dot blot hybridization

\begin{tabular}{lcccc}
\hline & \multicolumn{3}{c}{ Positive samples (total samples) } \\
\cline { 2 - 5 } Province & Cucurbitaceae & Solanaceae & Musaceae & Total \\
\hline Alajuela & $21(34)$ & $0(33)$ & $\ldots$ & $21(67)$ \\
Cartago & $14(39)$ & $3(26)$ & $\ldots$ & $17(65)$ \\
Guanacaste & $55(85)$ & $5(17)$ & $\ldots$ & $60(102)$ \\
Limón & $\ldots$ & $\ldots$ & $7(20)$ & $7(20)$ \\
San José & $8(30)$ & $\ldots$ & $\ldots$ & $8(30)$ \\
Total & $98(188)$ & $8(76)$ & $7(20)$ & $113(284)$ \\
\hline
\end{tabular}

${ }^{\mathrm{a}}$ Number of test plants infected with CMV (total number of test plants). control measures, such as the use of resistant cultivars, in these areas. Yield losses to crop plants in Costa Rica, which are largely grown for the international market and which provide a substantial portion of the country's economic basis, could become very significant if this trend continues.

\section{ACKNOWLEDGMENTS}

We thank G. Umaña, M. Guzmán, and A. Alfaro for assistance with the survey; and the many growers for their collaboration.

\section{LITERATURE CITED}

1. Beckler, G. S. 1992. Production of milligram amounts of highly translatable RNA using the RiboMAX system. Promega Notes 39:12-16.

2. Drew, R. A., Moisander, J. A., and Smith, M. K. 1989. The transmission of banana bunchytop virus in micropropagated banana. Plant Cell Tissue Organ Cult. 16:187-193.

3. Drew, R. A., Smith, M. K., and Anderson, D. W. 1992. Field evaluation of micropropagated bananas derived from plants containing banana bunchy-top virus. Plant Cell Tissue Organ Cult. 28:203-205.

4. Edwardson, J. R., and Christie, R. G. 1991. Cucumoviruses. Pages 293-319 in: CRC Handbook of Viruses Infecting Legumes. CRC Press, Boca Raton, FL.

5. García, A. J. 1998. Detección y variabilidad del cucumovirus del mosaico del pepino en Cucumis melo L. Department of Chemistry, Universidad de Costa Rica, San Jose.

6. Kaper, J. M., and Waterworth, H. E. 1981. Cucumoviruses. Pages 258-332 in: Handbook of Plant Virus Infections and Comparative Diagnosis. E. Kurstak, ed. Elsevier Biomedical Press, North Holland, Amsterdam.

7. Palukaitis, P., Roossinck, M. J., Dietzgen, R. G., and Francki, R. I. B. 1992. Cucumber mosaic virus. Pages 281-348 in: Advances in Virus Research. K. Maramorosch, F. A. Murphy, and A. J. Shatkin, eds. Academic Press, San Diego, CA.

8. Rivera, C., Ramírez, P., and Pereira, R. 1992. Preliminary characterization of viruses infecting banana in Costa Rica. Workshop Biotechnol. Appl. Banana Plantain Improve. San Jose, Costa Rica.

9. Rivera, C., Villalobos, W., Sánchez, M. V., Zumbado, C., and Rodríguez, C. M. 1993. Identification and distribution of meloninfecting viruses and their vectors in two provinces of Costa Rica. Turrialba 43:210215.

10. Rizzo, T. M., and Palukaitis, P. 1990. Construction of full-length cDNA clones of cucumber mosaic virus RNAs 1, 2 and 3: Generation of infectious RNA transcripts. Mol. Gen. Genet. 222: 249-256.

11. Roossinck, M. J., Bujorski, J., Ding, S. W., Hajimorad, R., Hanada, K., Scott, S., and Tousignant, M. 1999. Family Bromoviridae. Pages 923-935 in: Virus TaxonomySeventh Report of the International Committee on Taxonomy of Viruses. M. H. V. van Regenmortel, C. M. Fauquet, and D. H. L. Bishop, eds. Academic Press, San Diego, CA

12. Roossinck, M. J., Kaplan, I., and Palukaitis, P. 1997. Support of a cucumber mosaic virus satellite RNA maps to a single amino acid proximal to the helicase domain of the helper virus. J. Virol. 71:608-612.

13. Roossinck, M. J., and Palukaitis, P. 1990. Rapid induction and severity of symptoms in zucchini squash (Cucurbita pepo) map to RNA 1 of cucumber mosaic virus. Mol. Plant Microbe-Interact. 3:188-192.

Plant Disease / September 2001953 
14. Roossinck, M. J., Zhang, L., and Hellwald, K.-H. 1999. Rearrangements in the $5^{\prime}$ nontranslated region and phylogenetic analyses of cucumber mosaic virus RNA 3 indicate radial evolution of three subgroups. J. Virol. 73:6752-6758.

15. Sánchez, M. V., Aguero, R., and Rivera, C.
1998. Plantas hospederas de los virus mas importantes que infectan melón Cucumis melo (Cucurbitaceae) en Costa Rica. Rev. Biol. Trop. 46:13-25.

16. Singh, Z., Jones, R. A. C., and Jones, M. G. K. 1995. Identification of cucumber mosaic virus subgroup I isolates from banana plants affected by infectious chlorosis disease using RT-PCR. Plant Dis. 79:713-716.

17. Zhang, L., Hanada, K., and Palukaitis, P. 1994. Mapping local and systemic symptom determinants of cucumber mosaic cucumovirus in tobacco. J. Gen. Virol. 75:31853191. 